of the physical chemistry of steel-making ; Sir Robert Hadfield Medal (1955), to Mr. Tor Fjalar Holmberg, of Oy Vuoksenniska A.B., in appreciation of his meritorious service in improving the technique of the production of iron and steel at the Imatra Works, Finland; Andrew Carnegie Silver Medal (1954), to Mr. B. Cina for his paper on the effect of cold work on the gamma-alpha transformation in some ironnickel-chromium alloys ( $J$. Iron and Steel Inst., 177 406 ; 1954); Williams Prizes (1954), of $£ 100$ each, to W. Jackson for his paper on the use of cold coke oven gas and pitch-creosote firing in tilting furnaces (J., 178,378 ; 1954), R. McDonald for his paper on steelworks waste-heat boiler practice $(J ., 176,71$; 1954), and A. Stirling for his paper on the pelletizing of Northampton sand ironstones by vacuum extrusion (J., 177, 25; 1954).

\section{Diploma of Fellowship of the City and Guilds of London Institute}

THe Council of the City and Guilds of London Institute has conferred the diploma of fellowship upon the following past students of the City and Guilds College : Mr. A. McL. Mooney, deputy director of electrical engineering, Admiralty, a post in which he has been responsible for much special development work; Sir Ralph Reed, lately chairman of Albert E. Reed and Co., Ltd., paper manufacturers, who was paper controller for the Government during the Second World War; Dr. E. H. Rodd, formerly of the Dyestuffs Division, Imperial Chemical Industries, Ltd., whose work in the dyestuffs industry has been responsible for many advancements, both in fundamental knowledge and in industrial practice; $\mathrm{Mr}$. N. E. Rowe, technical director of Blackburn and General Aircraft, Ltd., formerly of the Ministry of Aircraft Production, and now president-elect of the Royal Aeronautical Society; Mr. C. W. Speirs, formerly of the Morgan Crucible Co., Ltd., London, and a pioneer in the application of carbon in the electrical industry.

\section{Training of Engineers}

A NEW method of training boys leaving public and grammar schools to become professional engineers capable of filling responsible engineering, administrative and sales positions in industry has recently been introduced by the General Electric Co., Ltd. It is an industry-based 'sandwich scheme' operated by the Company in conjunction with the Birmingham College of Technology. In future all boys selected by the Company for this training will, on leaving school at the age of eighteen, be given a five-year course, in which full-time sessions of six months at the College of Technology will alternate with six-month periods of industrial training in the Company's works. At the end of the course a young man will have gained exemption from the professional requirements of a body such as the Institution of Electrical Engineers, and will, if he remains with the Company have as good prospects in the Company as the man who has spent three years at the university followed by two years as a graduate apprentice. During the whole of the five-year course, the Company not only pays a student's college fees but also gives him suitable remuneration to cover his living expenses. Two country houses in the Midlands are used by the Company as halls of residence. Boys on the course have their national service deferred until its completion. The college and industrial elements of the course are planned as a whole and are sufficiently flexible to meet the needs of individual students. At the moment about sixty boys at the Birmingham College of Technology are Company student trainees on the first year of their course. In three years time this number will have risen to between 250 and 300 .

\section{Queen Elizabeth House : Oxford Centre for Com- monwealth Studies}

A charter has now been granted by H.M. the Queen to Queen Elizabeth House, Oxford, the now Oxford centre for Commonwealth studies, and in it the purpose of the foundation is defined as follows : to facilitate studies in political, economic, legal, administrative, social and cultural matters affecting the peoples of the British Commonwealth overseas and especially, but not exclusively, the peoples of the Colonies, Protectorates and other territories for which the Government in Britain is directly responsible; to provide a centre to which persons of authority or influence can resort for the study of such matters and the exchange of information; to assist such persons to obtain access to the academic resources of Oxford and elsewhere; and generally to act as a link between individuals and institutions concerned with these affairs. It will be noted that, when the project was first announced (see Nature, 174, $19 ; 1954$ ), Queen Elizabeth House was to be a centre for Colonial studies, but that this has now been broadened to include Commonwealth studies generally, though the Colonial aspect is still the prime one. The Government has appointed Viscount Chandos as president of the governing body of Queen Elizabeth House, which will consist also of the vice-chancellor of the University of Oxford ex officio, four members appointed by the Government, four appointed by the University of Oxford and not more than eight appointed jointly by the Government and the University. The names of most of the members have been announced. Subject to confirmation, temporary quarters for the House have been secured in St. Giles, Oxford.

\section{Abstracts of Instrument Techniques}

THE one hundred and fourth issue of the Bulletin of the British Scientific Instrument Research Association (9, No. 11; November 1954) contains the twentythousandth abstract, compiled by the Association, of literature about scientific instruments published during the past nine and a half years, and gives an indication of the growth in importance of the science of instrumentation. 'The index to Vol. 8 (1953) of the Bulletin, which is now available, consists of an author and subject index to the 2,769 abstracts published during 1953 and covers some three hundrod pages. Members of the Association and non-member organizations and individuals engaged in branches of industry or research where it is important to keep abreast of new developments in instruments, techniques and methods of measurement will find the Bulletin most valuable for handy reference and as an informative guide to the literature.

\section{Meeting in New Mexico on Problems of Arid Lands}

THE American Association for the Advancement of Science is arranging an international meeting on "Arid Lands", to be held in New Mexico during April 26-May 4. The programme will consist of a symposium, on "What is the Future of Arid Lands?", during April 26-29 in the University of Now Moxico, Albuquerque, at which there will be a discussion 